\title{
IGF2, IGF binding protein 1, and matrix metalloproteinases 2 and 9 in implantation-stage endometrium following immunoneutralization of vascular endothelial growth factor in the rhesus monkey
}

\author{
D Ghosh, A R Najwa, M A Khan and J Sengupta \\ Department of Physiology, All India Institute of Medical Sciences, New Delhi 110029, India
}

Correspondence should be addressed to J Sengupta; Email: jsen47@gmail.com

\begin{abstract}
Blastocyst implantation in the rhesus monkey is inhibited by administration of antibody against vascular endothelial growth factor (VEGF) A during peri-implantation period with no change in the circulatory concentrations of estradiol, progesterone, and VEGF. In this study, we have investigated the effect of administration of a MAB to VEGFA on days 5 and 10 after ovulation upon the mRNA expression, immunopositive protein expression, and immunohistological localization of IGF2, IGF binding protein 1 (IGFBP1) and matrix metalloproteinases (MMPs) 2 and 9 in the implantation-stage endometrium collected on day 13 after ovulation from fecund cycles of rhesus monkeys. The comparison between isotype-matched IgG (control; $n=8$ )- and VEGF antibody (VEGF Mab; $n=8$ )-treated animals revealed higher $(\boldsymbol{P}<\mathbf{0 . 0 5})$ IGF2 in lacunar and villous syncytiotrophoblasts, trophoblast cell columns, migrating extravillous trophoblast cells, and endovascular trophoblast cells in control animals, but with no change in the various cell types of maternal endometrium between the two groups. No change in IGFBP1 expression in the endometrium was observed between the two groups. MMPs 2 and 9 were detected in syncytiotrophoblast in lacunae and villi, trophoblast cell columns, and extravillous trophoblast cells in control samples. MMP9 transcript expression in maternal endometrium and its immunopositivity in endometrial stroma and trophoblast cells were lower $(\boldsymbol{P}<\mathbf{0 . 0 5})$ with no change in MMP2 level in VEGF Mab-exposed samples compared with those in control samples. A functional network involving VEGF, IGF2, and MMP9 in early placental trophoblast cells and maternal endometrium appears to be important for normal placentation.
\end{abstract}

Reproduction (2011) 141 501-509

\section{Introduction}

Blastocyst implantation in the rhesus monkey is initiated around days 7-9 after ovum fertilization. During early stage of implantation, syncytiotrophoblast cells intrude between epithelial cells to penetrate through the basal lamina, rapidly expand in the lateral plane of the uterine endometrium, and tap subepithelial capillaries to establish the early stage of placentation on days 12-13 after fertilization in the rhesus monkey (Enders 1995, Sengupta \& Ghosh 2002). An obligatory component of the above-mentioned implantation-associated endometrial responses is a marked change in the vascular component under the action of vascular endothelial growth factor (VEGF; Ghosh et al. 2000, Wulff et al. 2002). Timed systemic administration of a neutralizing $M A B$ directed against VEGFA resulted in pregnancy failure, and it was associated with shallow trophoblastic invasion, however, with no change in the concentrations of estradiol- $17 \beta\left(E_{2}\right)$, progesterone, and free VEGF in the peripheral circulation (Sengupta et al. 2007).
Cytotrophoblast differentiation along the invasive pathway is a complex multistep process. As the cells lose their proliferative ability, they invade the uterine wall by expressing specific matrix metalloproteinases (MMPs; Xu et al. 2001, Staun-Ram et al. 2004). It has been demonstrated that VEGF and MMPs 2 and 9 may comprise a functional network regulating the invasive phenotype in a variety of cell types including trophoblast cells (Anteby et al. 2004, Hollborn et al. 2007). Also, it appears that a critical balance of insulin-like growth factors (IGFs) and their binding proteins between trophoblast cells and decidual cells may regulate the invasive property of trophoblast cells (Dhara et al. 2001, Irwin et al. 2001, Nayak \& Giudice 2003). On the other hand, our previous report suggested that insufficient trophoblast invasion was the likely major causative factor in pregnancy failure in rhesus monkeys subjected to anti-VEGF antibody treatment (Sengupta et al. 2007). Taken together, in this study, we have investigated the effect of administration of a MAB to VEGFA during days 
5-10 after ovulation upon IGF2, IGF binding protein 1 (IGFBP1), MMP2, and MMP9 in the implantation-stage endometrium of the rhesus monkey.

\section{Results}

Tables 1 and 2 show the scores of immunohistochemical (IHC) staining for different candidate proteins in day 13 lacunar-stage primary implantation sites of rhesus monkeys treated with or without VEGF Mab.

The feto-maternal interface in samples collected from both control (Fig. 1A)- and VEGF Mab (Fig. 1B)-treated animals showed immunopositivity for IGF2 in plaque, glandular, and stromal decidual cells with no marked difference between the two groups (Table 1). No overall change in the transcript and protein expressions for IGF2 was observed between the two groups in the endometrium, except a marginal attenuation of its expression in VEGF Mab-treated endometrium compared with control-treated implantation-stage endometrium (Tables 1 and 3). As shown in Fig. 1, at sites of embryo implantation, IGF2 was detected in trophoblast cells

Table 1 Rank scores of immunopositive levels of insulin-like growth factor 2 (IGF2) and insulin-like growth factor binding protein 1 (IGFBP1) in conceptus and endometrium at primary implantation sites collected on day 13 after ovulation from rhesus monkeys injected s.c. with isotype-matched mouse $\operatorname{lgG}(n=8)$ or monoclonal mouse antibody against VEGFA (VEGF Mab, $n=8$ ) on days 5 and 10 after ovulation.

\begin{tabular}{|c|c|c|c|c|}
\hline \multirow[b]{2}{*}{ Cell type } & \multicolumn{2}{|c|}{ IGF2 } & \multicolumn{2}{|c|}{ IGFBP1 } \\
\hline & $\lg G$ & $\begin{array}{l}\text { VEGF } \\
\text { Mab }\end{array}$ & $\lg G$ & $\begin{array}{l}\text { VEGF } \\
\text { Mab }\end{array}$ \\
\hline \multicolumn{5}{|l|}{ Conceptus } \\
\hline $\begin{array}{l}\text { Cytotrophoblast cells } \\
\text { within chorionic } \\
\text { membrane }\end{array}$ & $0(0-2)$ & $2(1-3)$ & ND & ND \\
\hline $\begin{array}{l}\text { Cytotrophoblast cells } \\
\text { (lacunar and villous) }\end{array}$ & $2(1-3)^{*}$ & $0(0-1)$ & ND & ND \\
\hline $\begin{array}{l}\text { Syncytiotrophoblast cells } \\
\text { (lacunar and villous) }\end{array}$ & $3(2-4)^{*}$ & $0(0-1)$ & ND & ND \\
\hline $\begin{array}{l}\text { Non-polarized } \\
\text { cytotrophoblast cells in } \\
\text { cell columns }\end{array}$ & $2(1-3)^{*}$ & $0(0-1)$ & ND & ND \\
\hline $\begin{array}{l}\text { Syncytiotrophoblast cells } \\
\text { lining cell columns }\end{array}$ & $2(1-3)^{*}$ & $0(0-1)$ & ND & ND \\
\hline $\begin{array}{l}\text { Endovascular trophoblast } \\
\text { cells }\end{array}$ & $2(1-3)^{*}$ & $0(0-1)$ & ND & ND \\
\hline $\begin{array}{l}\text { Extravillous trophoblast } \\
\text { cells }\end{array}$ & $2(1-3)^{*}$ & $0(0-1)$ & ND & ND \\
\hline Heterokaryons & $3(2-4)$ & $3(1-3)$ & $1(0-2)$ & $1(0-3)$ \\
\hline \multicolumn{5}{|l|}{ Endometrium } \\
\hline \multicolumn{5}{|l|}{ Epithelium } \\
\hline Luminal & $2(1-3)$ & $2(1-3)$ & $1(0-3)$ & $1(0-3)$ \\
\hline Glandular & $2(2-4)$ & $2(2-4)$ & $2(1-4)$ & $2(1-3)$ \\
\hline Plaque & $2(2-4)$ & $2(2-4)$ & ND & ND \\
\hline Stromal/decidual cells & $2(2-4)$ & $1(1-3)$ & $2(1-3)$ & $2(1-3)$ \\
\hline Endothelial cells & $0(0-1)$ & $0(0-1)$ & ND & ND \\
\hline
\end{tabular}

ND, not detected. Scoring was done using a standardized 5-scale system: $0(<5 \%), 1(5-25 \%), 2(26-50 \%), 3(51-75 \%)$, and $4(76 \%$ and more). ${ }^{*} P<0.05$.
Table 2 Rank scores of immunopositive levels of matrix metalloproteinases (MMPs) 2 and 9 in conceptus and endometrium at primary implantation sites collected on day 13 after ovulation from rhesus monkeys injected s.c. with isotype-matched mouse $\lg G(n=8)$ or monoclonal mouse antibody against VEGFA (VEGF Mab, $n=8$ ) on days 5 and 10 after ovulation.

\begin{tabular}{|c|c|c|c|c|}
\hline \multirow[b]{2}{*}{ Cell type } & \multicolumn{2}{|c|}{ MMP2 } & \multicolumn{2}{|c|}{ MMP9 } \\
\hline & $\lg G$ & $\begin{array}{l}\text { VEGF } \\
\text { Mab }\end{array}$ & $\lg G$ & $\begin{array}{l}\text { VEGF } \\
\text { Mab }\end{array}$ \\
\hline \multicolumn{5}{|l|}{ Conceptus } \\
\hline $\begin{array}{l}\text { Cytotrophoblast cells } \\
\text { within chorionic } \\
\text { membrane }\end{array}$ & ND & ND & $1(0-2)$ & $2(0-3)$ \\
\hline $\begin{array}{l}\text { Cytotrophoblast cells } \\
\text { (lacunar and villous) }\end{array}$ & $1(0-2)$ & $0(0-1)$ & $3(2-4)^{*}$ & $0(0-1)$ \\
\hline $\begin{array}{l}\text { Syncytiotrophoblast cells } \\
\text { (lacunar and villous) }\end{array}$ & $0(0-1)$ & $0(0-1)$ & $3(2-4)^{*}$ & $0(0-1)$ \\
\hline $\begin{array}{l}\text { Non-polarized } \\
\text { cytotrophoblast cells in } \\
\text { cell columns }\end{array}$ & $0(0-1)$ & $0(0-1)$ & $2(1-3)^{*}$ & $0(0-1)$ \\
\hline $\begin{array}{l}\text { Syncytiotrophoblast cells } \\
\text { lining cell columns }\end{array}$ & $0(0-1)$ & $0(0-1)$ & $3(2-4)^{*}$ & $0(0-1)$ \\
\hline $\begin{array}{l}\text { Endovascular trophoblast } \\
\text { cells }\end{array}$ & $0(0-1)$ & $0(0-1)$ & $2(1-3)^{*}$ & $0(0-1)$ \\
\hline $\begin{array}{l}\text { Extravillous trophoblast } \\
\text { cells }\end{array}$ & $1(0-1)$ & $0(0-1)$ & $3(2-4)^{*}$ & $0(0-1)$ \\
\hline Heterokaryons & $1(0-1)$ & $1(0-1)$ & $3(2-4)$ & $2(1-3)$ \\
\hline \multicolumn{5}{|l|}{ Endometrium } \\
\hline \multicolumn{5}{|l|}{ Epithelium } \\
\hline Luminal & $2(1-3)$ & $1(0-2)$ & $2(1-3)$ & $1(1-3)$ \\
\hline Glandular & $1(0-2)$ & $1(1-2)$ & $2(2-4)$ & $2(2-3)$ \\
\hline Plaque & $2(1-3)$ & $1(1-3)$ & $2(1-3)$ & $2(0-4)$ \\
\hline Stromal/decidual cells & $1(0-2)$ & $1(0-2)$ & $3(2-4)^{*}$ & $1(0-3)$ \\
\hline Endothelial cells & $1(1-2)$ & $1(0-1)$ & $2(2-3)$ & $1(1-3)$ \\
\hline
\end{tabular}

ND, not detected. Scoring was done using a standardized 5-scale system: $0(<5 \%), 1(5-25 \%), 2(26-50 \%), 3(51-75 \%)$, and $4(76 \%$ and more). ${ }^{*} P<0.05$.

lining lacunae and early villi, in trophoblast cell columns, in migrating extravillous trophoblast and in endovascular trophoblast cells in control animals (Fig. 1A) confirming our earlier report (Dhara et al. 2001). However, samples from VEGF Mab-treated animals showed a significantly $(P<0.05)$ lower expression of IGF2 in trophoblast cells (Fig. 1B). Although IGF2 was detected in trophoblast cells lying within the chorionic membrane and in heterokaryons formed by symplasma of lining uterine epithelial cells and trophoblast cells at the implantation site in VEGF Mab-exposed samples, trophoblast cells at invasive front exhibited lower $(P<0.05)$ immunostaining for IGF2 (Table 1; Fig. 1B). The profiles of IGFBP1 were similar in decidualized stromal cells surrounding trophoblast cells and plaque cells and within the chorionic plate, and in glandular epithelium between samples collected from control (Fig. 1C)- and VEGF Mab (Fig. 1D)-treated animals (Table 1). The results of estimations of RNA and protein for IGFBP1 in the endometrium of both groups (Table 3) substantiated the IHC observation.

Table 2 shows that a substantial level of MMP9 was detected in trophoblast cells lining lacunae and villi, in 
Table 3 mRNA and protein expression of insulin-like growth factor 2 (IGF2), insulin-like growth factor binding protein 1 (IGFBP1), matrix metalloproteinases (MMPs) 2 and 9 in the implantation-stage endometrium collected on day 13 after ovulation from rhesus monkeys injected s.c. with isotype-matched mouse $\operatorname{lgG}(n=8)$ or monoclonal mouse antibody against VEGFA (VEGF Mab, $n=8$ ) on days 5 and 10 after ovulation.

\begin{tabular}{lcclcc}
\hline & \multicolumn{2}{c}{ IgG } & & \multicolumn{2}{c}{ VEGF Mab } \\
\cline { 2 - 3 } \cline { 5 - 6 } Name & RNA $^{\mathrm{a}}$ & Protein $^{\mathrm{b}}$ & & RNA $^{\mathrm{a}}$ & Protein $^{\mathrm{b}}$ \\
\hline IGF2 & $4.9 \pm 0.2$ & $3.9 \pm 0.2$ & & $4.1 \pm 0.4$ & $3.6 \pm 0.1$ \\
IGFBP1 & $4.7 \pm 0.3$ & $4.1 \pm 0.3$ & & $4.8 \pm 0.4$ & $4.0 \pm 0.2$ \\
MMP2 & $6.0 \pm 0.1$ & $4.2 \pm 0.2$ & & $5.8 \pm 0.2$ & $4.1 \pm 0.3$ \\
MMP9 & $2.7 \pm 0.4$ & $4.2 \pm 0.1$ & & $1.8 \pm 0.3^{*}$ & $3.9 \pm 0.3$ \\
\hline
\end{tabular}

$* P<0.05$

a Log of copy number per $\mu$ g RNA. ${ }^{b}$ Integrated optical density normalized by that of $\beta$-actin per $25 \mu$ g protein.

trophoblast cell columns, and also in an invasive population of extravillous trophoblast cells within the endometrial bed at the feto-maternal interface in control samples (Fig. 2B), but these cells showed only marginal level of MMP2 (Fig. 2A). MMP9 (Fig. 2C) was found to be lower $(P<0.05)$ in trophoblast cells with no change in MMP2 expression level (Fig. 2D) in VEGF Mab-exposed samples compared with that in control samples (Table 2). Plaque cells and heterokaryons as well as cells in epithelial and vascular compartments at sites adjoining implantation sites were positive for MMP2 (Fig. 2A and D) and markedly positive for MMP9 (Fig. 2B and C) in both groups with no marked difference between the two groups (Table 1). No marked change was observed in MMP2 transcript and protein expression in maternal endometrium between control-treated and VEGF Mabtreated groups (Tables 2 and 3). However, implantationstage maternal endometrium showed higher MMP9 expression $(P<0.05)$ in stromal compartment of control samples (Fig. $2 \mathrm{H}$ ) compared with that in VEGF Mabexposed samples (Fig. 2F and I) in immunohistological analysis, as well as, in the estimation of RNA, but not in the estimation of protein for MMP9 in the endometrium of both groups (Tables 2 and 3). MMP9-positive endovascular trophoblast cells (Fig. 2E and $\mathrm{H}$ ) were clearly detected in IgG-exposed control animals, while VEGF Mab-exposed samples failed to reveal MMP9positive endovascular trophoblast cells. MMP9 level in glandular epithelium was similar between control (Fig. 2K)- and VEGF Mab (Fig. 2L)-treated samples (Table 2).

\section{Discussion}

The process of trophoblastic invasion involves remodeling of uteroplacental blood vessels and extracellular matrix (Cohen \& Bischof 2007). As pointed out in the following section, three candidates appear to be important players in the process.
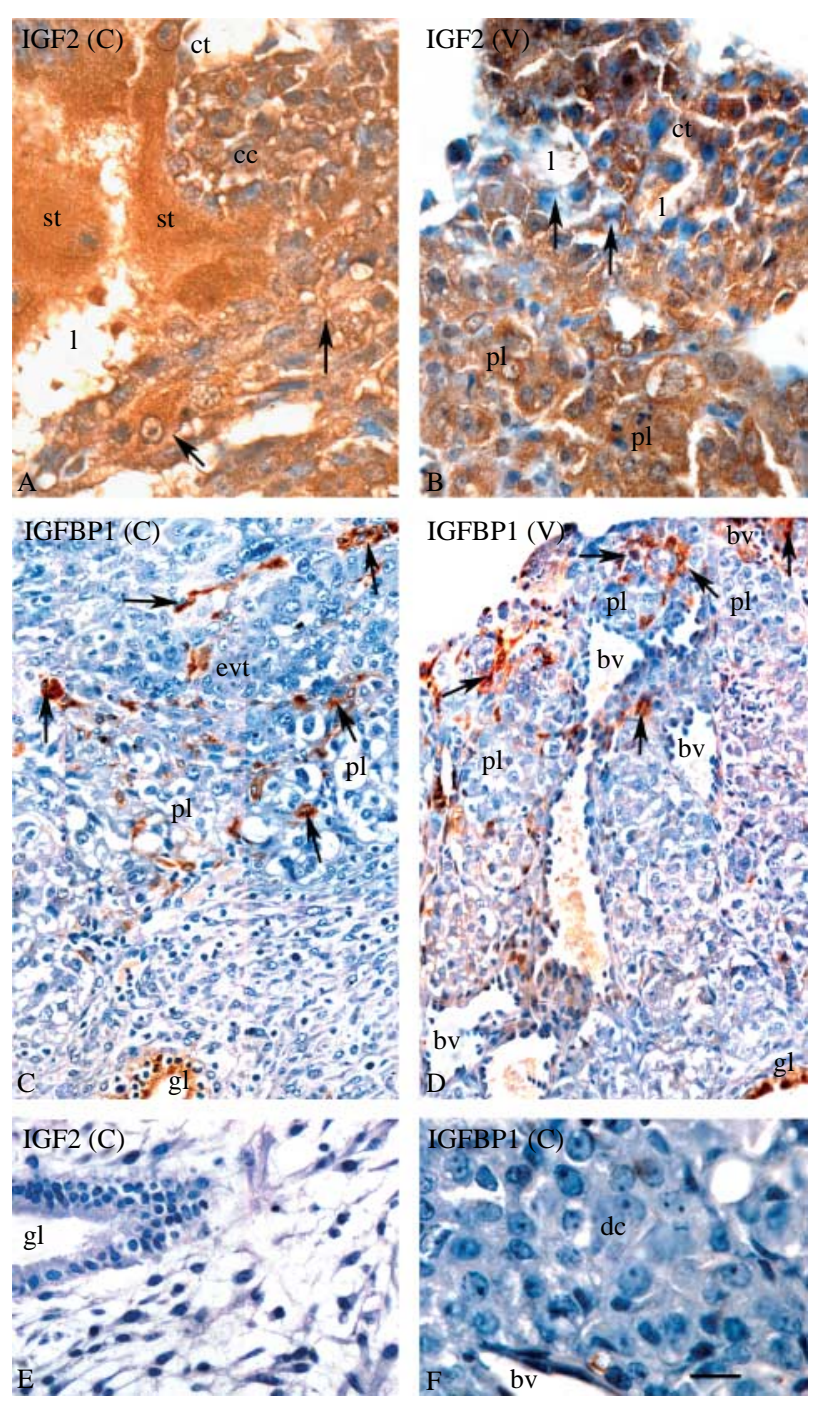

Figure 1 Immunohistochemical localization of insulin-like growth factor 2 (IGF2; A, B, and E) and insulin-like growth factor binding protein 1 (IGFBP1; C, D, and F) in primary implantation sites obtained on day 13 after ovulation from animals treated with control isotypematched IgG (A, C, E, and F) shown as (C) or anti-VEGF Mab (B and D) shown as (V). Higher degree of immunopositive staining for IGF2 is observed in cytotrophoblast and syncytiotrophoblast lining lacunae and villi, in cytotrophoblast cell columns, in migrating extravillous trophoblast cells (arrows) in control samples (A) compared with that in anti-VEGF Mab-treated samples (B). Gland cells and decidual cells (arrows) surrounding plaque cells, migrating front of extravillous trophoblast cells, and adjacent to blood vessels show clear immunopositivity for IGFBP1 in both control (C)- and anti-VEGF Mab-treated (D) samples. No staining is observed in control immunohistochemistry for IGF2 and IGFBP1 in primary implantation site samples with medium containing pre-neutralized primary antibody against IGF2 (E) and medium containing pre-neutralized primary antibody against IGFBP1 (F) respectively. bv, blood vessel; cc, cytotrophoblast cell column; ct, cytotrophoblast; dc, decidual cell; evt, extravillous trophoblast cell; gl, gland cell; I, lacunae; pl, plaque cells; st, syncytiotrophoblast. Bar $=40 \mu \mathrm{m}(\mathrm{F}), 50 \mu \mathrm{m}(\mathrm{A}, \mathrm{B}$, and $\mathrm{E})$, and $60 \mu \mathrm{m}$ (C and D). 


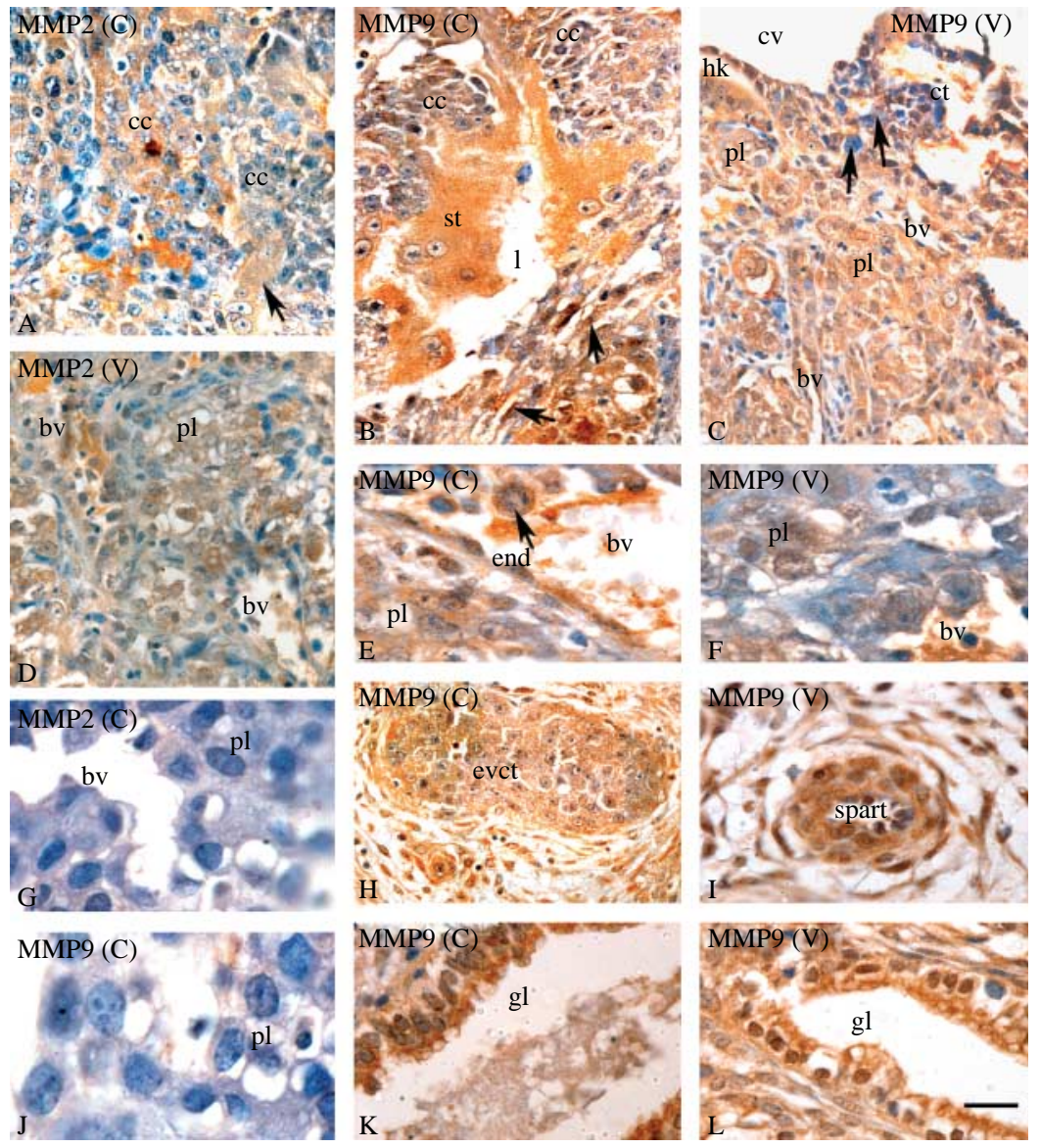

Figure 2 Immunohistochemical localization of matrix metalloproteinase 2 (MMP2; A, D, and G) and matrix metalloproteinase 9 (MMP9; B, C, E, F, $\mathrm{H}-\mathrm{J}, \mathrm{K}$, and $\mathrm{L}$ ) in primary implantation sites obtained on day 13 after ovulation from animals treated with control isotype-matched IgG (A, B, E, G, H, J, and K) shown as (C) or anti-VEGF Mab (C, D, F, I, and L) shown as (V). Low level of MMP2 is observed in cytotrophoblast cells of cell columns and in migrating extravillous trophoblast cells (arrow) in control animal (A) and in plaque cells of VEGF Mab-treated animal (D). Marked MMP9 is observed in cytotrophoblast cells of cell columns, syncytiotrophoblast cells lining lacunae, migrating extravillous trophoblast cells (arrow) (B), trophoblast cell (arrow) invading into blood vessel (E), endovascular cytotrophoblast cells (H), and glandular epithelial cells (K). MMP9 is observed in plaque cells and decidual cells adjoining blood vessel (C, F, and I), glandular epithelium (L), while cytotrophoblast cells within chorionic cavity show variable and cytotrophoblast cells at feto-maternal junction (arrows) show negative staining for MMP9 in VEGF Mab-treated sample (C). Heterokaryons that are fused maternal epithelial cells and cytotrophoblast cells found at the outer margin of feto-maternal interface show immunopositivity for MMP9 (C). No staining is observed in control immunohistochemistry for MMP2 and MMP9 with medium containing preneutralized primary antibody for MMP2 (G) and medium containing pre-neutralized primary antibody against MMP9 (J) respectively. bv, blood vessel; cc, cytotrophoblast cell column; cv, chorionic cavity; ct, cytotrophoblast; dc, decidual cell; end, endothelial cells; evct, endovascular cytotrophoblast cell; gl, gland cell; hk, heterokaryon; I, lacunae; pl, plaque cells; spart, spiral arteriole; st, syncytiotrophoblast. Bar $=45 \mu \mathrm{m}$ (G and $\mathrm{J}), 60 \mu \mathrm{m}(\mathrm{B}, \mathrm{E}, \mathrm{F}, \mathrm{K}$, and $\mathrm{L})$, and $70 \mu \mathrm{m}(\mathrm{A}, \mathrm{C}, \mathrm{D}, \mathrm{H}$, and $\mathrm{I})$.

(1) VEGF: there is an up-regulated expression of VEGF and its receptors during the early stages of gestation (Ghosh et al. 2000, Schiessl et al. 2009) that directly or indirectly results in endometrial perfusion, trophoblast proliferation, and trophoblast invasion (Staun-Ram \& Shalev 2005). These findings taken together with the observation that VEGF and its receptors are down-regulated in placental samples of pre-eclampsia (Zhou et al. 2002, Jarvenpaa et al. 2009) suggest that a defect in angiogenic function may result in defective trophoblastic invasion and placentation process (Jauniaux et al. 2003, Prefumo et al. 2004, Ferretti et al. 2007). The suggestion is corroborated by the observation that timed systemic administration of VEGF Mab in the peri-implantation period in the rhesus monkey resulted in compromised expression of VEGF and its receptors along with shallow invasion and pregnancy failure in the rhesus monkey (Sengupta et al. 2007). The results of this study also substantiate the above observation.

(2) IGF2: of the two major IGF types, IGF2 in lamellar syncytiotrophoblast cells specifically functions in their transition from proliferating to differentiated state, potentiating trophoblast migration within the chorionic plate (Dhara et al. 2001, Nayak \& Giudice 2003). On the maternal side, uterine decidua expresses high levels of basement 
membrane-type extracellular matrix and secretes IGFBP1 (Ghosh et al. 2004). The results of this study also substantiate the above observation. Interestingly, IGFBP1 expression in maternal endometrium exhibits temporal and spatial patterns specific to conceptus-derived signals (Ghosh et al. 2004). The function of IGF2-IGFBP1 at the feto-maternal interface may thus involve a delicate balance between invasion and its suppression toward normal placentation (Irwin et al. 2001, Forbes \& Westwood 2008). In this study, we observed that administration of anti-VEGF antibody that had resulted in implantation failure (Sengupta et al. 2007) was associated with down-regulation of IGF2 in the trophoblast and with its marginal decreased expression in protein and transcript levels along with no change in IGFBP1 level in the maternal endometrium.

(3) MMPs: substantial evidence suggests that gelatinase-type MMPs, especially MMP2 (gelatinase A) and MMP9 (gelatinase B), play a crucial role in the process of trophoblast invasion, and their inadequacy may result in defective placentation (Nagase \& Woessner 1999, Bischof \& Irminger-Finger 2005). It now appears that MMP9 expression/ activation is critical for trophoblast invasion and its expression is markedly reduced with no change in MMP2 expression in the pre-eclamptic placentas (Ferretti et al. 2007, Shokry et al. 2009). In this study, we also observed that administration of antiVEGF antibody that had resulted in implantation failure (Sengupta et al. 2007) was associated with down-regulation of MMP9 in trophoblast cells along with decrease in its transcript copy number in stromal compartment of the maternal endometrium without any change in MMP2 expression.

Thus, we observed in this study that failed angiogenic function in early placenta following administration of anti-VEGF antibody resulted in shallow invasion associated with an attenuation of IGF2 and MMP9 in trophoblast cells without influencing IGFBP1 in maternal endometrium and MMP2 in placental trophoblast cells. This is consistent with the notion that inadequate angiogenic function may result in defective trophoblastic invasion (Jauniaux et al. 2003, Prefumo et al. 2004, Egbor et al. 2006). It also appears that a functional network involving VEGF-IGF2-MMP9 is operative in the physiological process of trophoblast invasion in the rhesus monkey. As discussed below, several lines of indirect evidence indeed indicate that a putative functional network involving VEGF-IGF2MMPs in trophoblast cells is important in the process of placentation.

The angiogenic switch under hypoxic stress generally involves both major gelatinases (MMP2 and MMP9); MMP9 may influence synthesis and secretion of VEGF in non-trophoblast cells (Hollborn et al. 2007). Also pro-angiogenic and pro-metastatic molecules such as VEGF and MMP9 have common promoter regions containing binding sites for nuclear transcription factors, NF- $\kappa \mathrm{B}$ and $\mathrm{AP}-1$, that regulate proliferation, apoptosis, angiogenesis, and invasion (Uzzo et al. 2006, Cohen et al. 2008). MMP9 may also exert a modulator activity in the VEGF-induced regulation of trophoblast invasion and migratory functions (Lash et al. 1999, 2003, Anteby et al. 2004). The reduced expression of MMP9 has been linked with insufficient invasion of trophoblast in preeclamptic placentas (Shokry et al. 2009). Taken together and based on the results of this study, a central role of MMP9 and VEGF in trophoblast invasion and vascular remodeling in the placentation process can be suggested (Tsatsaris et al. 2003, Prefumo et al. 2004, Papageorghiou et al. 2008).

IGF2 regulates the role of syncytiotrophoblast cells in placental functions of nutrient and oxygen transport, and it potentiates the migratory functions of trophoblast cells in the chorionic plate (Irving \& Lala 1995, Dhara et al. 2001). IGF2 signaling has been found to up-regulate VEGF function in part by increasing hypoxia-inducing factor (Kwon et al. 2004, Kim \& Kim 2005). Interestingly, we did not observe any change in endometrial IGFBP1 between anti-VEGF antibodytreated and control samples, despite lower expression of IGF2 in trophoblast cells in anti-VEGF antibody-treated samples. It appears possible that placental alkaline phosphatase might influence the degree of phosphorylation of IGFBP1 and thereby could affect the IGFbinding affinity of IGFBP1, for example non-phosphorylated IGFBP1 isoform shows reduced affinity for IGF1 (Westwood et al. 1994, Yu et al. 1998). Although we observed a marked reduction in placental immunopositive alkaline phosphatase expression in anti-VEGF antibody-exposed samples compared with control samples (data not shown), it is likely that nonphosphorylated IGFBP1 does not show marked difference in the specific binding affinity for IGF2 compared with phosphorylated IGFBP1 (Coppock et al. 2004). On the other hand, it is rather likely that reduced MMP9 in maternal endometrial decidual cells following anti-VEGF antibody treatment in this study might have resulted in a higher relative availability of phosphorylated IGFBP1 at feto-maternal interface resulting in an attenuated IGF2 activity (Forbes \& Westwood 2008).

Collectively, it appears that hypoxia-sensitive extravillous trophoblast cells may show positive cooperation involving VEGF, IGF2, and MMP9 in invasive cytotrophoblast cells within a hypoxic milieu, thereby modulating early gestational trophoblast invasive functions in normal placentas. Insufficiency in the functional networks of VEGF-IGF2-MMPs as triggered by anti-VEGF antibody may result in defective placentation and pregnancy failure. 


\section{Materials and Methods}

\section{Animals}

Proven fertile adult female rhesus monkeys (age 5-7 years; $n=18$ ) showing two consecutive normal menstrual cycles of 26-30 days were placed for mating during cycle days 8-16 with proven fertile adult male monkeys (age $6-8$ years; $n=10$ ). Peripheral blood samples were collected for hormone assays, and vaginal smears were checked daily for the presence of spermatozoa and/or sperm plug. Ovulation was detected from the peripheral steroid hormonal profile for $E_{2}$ and progesterone (P) as detected using rapid assay (Sengupta et al. 2007). The assumed day of ovulation was taken $24 \mathrm{~h}$ after peak rise of $E_{2}$ in peripheral circulation and with detectable rise in serum $\mathrm{P}$ level (Ghosh \& Sengupta 1993). Vaginal smears were microscopically scored on a grade scoring system recommended by the World Health Organization (WHO 2003). Of the 18 animals, two failed to show ovulation, and the remaining 16 animals that showed positive ovulation and sufficient sperm profiles were randomly assigned into two groups: control $(n=8)$ animals that received $10 \mathrm{mg}$ isotype-matched mouse IgG, and experimental $(n=8)$ animals that received $10 \mathrm{mg}$ monoclonal mouse antibody against VEGFA (VEGF Mab) between 1000 and $1030 \mathrm{~h}$ of days 5 and 10 after ovulation. The IgGs were prepared in $2 \mathrm{ml}$ sterile PBS, pH 7.2 and injected s.c. as reported elsewhere (Sengupta et al. 2007). On day 13 after ovulation, all animals were laparotomized under ketamine anesthesia (12 mg/kg body weight, Parke Davis, Mumbai, India) for performing hysterectomy under aseptic conditions to collect implantation-stage maternal endometrium (Ghosh et al. 1999, Sengupta et al. 2003). The Primate Research Facility of the All India Institute of Medical Sciences provided routine care and management of the monkeys used in this study. The study was conducted with the approval of the ethics committee for the Use of Non-Human Primates for Biomedical Research, All India Institute of Medical Sciences, New Delhi. The source materials employed in this study were obtained from the animals that were used in a previous study (Sengupta et al. 2007).

\section{Tissue processing}

Uterine corpus was carefully removed and washed in ice-cold PBS ( $\mathrm{pH}$ 7.2) to remove adherent blood and examined under stereozoom microscope to identify the primary implantation site. Implantation sites were sliced out and immediately fixed in cold neutral phosphate-buffered paraformaldehyde $(4 \%$, $\mathrm{w} / \mathrm{v})$. Samples were embedded in paraffin wax, and $5 \mu \mathrm{m}$ paraffin sections were processed for routine histology and immunohistochemistry (Sengupta et al. 2003. Ghosh et al. 2004). The details of immunohistochemistry are described below. Endometrial areas adjacent to the implantation site were sliced out from all samples and directly used for protein and RNA extraction as described below.

\section{Immunohistochemistry}

IHC staining for IGF2, IGFBP1, MMP2 and MMP9 in fetal and maternal compartments were performed in three randomly selected section specimens from individual samples (control treated, $n=8$; VEGF Mab treated: $n=8$ ) using optimized methodology as described previously (Dhara et al. 2001, Kar et al. 2007). Briefly, $5 \mu \mathrm{m}$ deparaffinized sections were subjected to blockade for endogenous peroxidase activity and non-specific binding followed by incubation with primary antibodies overnight at $4{ }^{\circ} \mathrm{C}$ and then with biotinylated secondary antibody. Dilutions of stock primary antibodies for incubation were pre-calibrated based on 3-5-point titration and the information provided by the manufacturer. The sources of primary antibodies and the dilutions at which they were used in this study are shown in Table 4. Final visualization was achieved using the $\mathrm{ABC}$ peroxidase Elite kits (Vector Laboratories, Burlingame, CA, USA) and freshly prepared 3,3'-diaminobenzidine hydrochloride with hydrogen peroxide (Sigma Chemical Co.). The color characteristics of immunopositive staining ranged between brown and rust color. The nuclei were counterstained with Gill's hematoxylin. Specificity of the antibody binding was assessed by omitting primary antibodies, immunoadsorption of primary antibodies with target peptides, replacing primary antibodies with unrelated $\lg$ from same species and other species, omitting secondary antibodies, and replacing secondary antibodies with unrelated IgGs from same or other species in parallel sections from each sample (control IgG, $n=8$; VEGF Mab, $n=8$ ). Labeled and unlabeled IgGs, non-immune sera, and other supplies were purchased from Vector Laboratories and Sigma Chemical Co.

\section{Microscopic image analysis}

The images were viewed and documented using a Leica DMRD microscope (Leica Microsystems, Wetzlar $\mathrm{GmbH}$, Germany) and were analyzed by a computer-assisted subjected image analysis system (Leica QWIN DC 200, Cambridge, UK). The criteria for identification for different cell types have been described elsewhere (Enders 1993, Dhara et al. 2001). Multinuclear heterokaryons were identified at the periphery of the primary placenta with histology atypical to trophoblast and luminal epithelium as described by Enders (1993). It was, however, not certain whether the marginal ring of

Table 4 Characteristics of primary antibodies used in immunohistochemical (IHC) and immunoblot (WB) analyses of implantation-stage endometrium following maternal inhibition of vascular endothelial growth factor.

\begin{tabular}{|c|c|c|c|c|}
\hline \multirow[b]{2}{*}{ Antigen } & \multirow{2}{*}{$\begin{array}{l}\text { Specification of antisera } \\
\text { (Catalog number) }\end{array}$} & \multicolumn{2}{|c|}{$\begin{array}{l}\text { Dilution } \\
(\mu \mathrm{g} / \mathrm{ml})\end{array}$} & \multirow[b]{2}{*}{ Source } \\
\hline & & $\mathrm{IHC}$ & WB & \\
\hline$\beta$-actin & Sheep IgG (AF 4000) & - & 2.0 & R\&D Systems ${ }^{a}$ \\
\hline IGF2 & Goat IgG (AF292) & 5.0 & 2.0 & R\&D Systems ${ }^{a}$ \\
\hline IGFBP1 & Mouse IgG & 0.5 & 0.2 & S C Bell ${ }^{b}$ \\
\hline MMP2 & Goat IgG (AF902) & 5.0 & 2.0 & R\&D Systems ${ }^{a}$ \\
\hline MMP9 & Mouse IgG (MAB911) & 5.0 & 2.0 & R\&D Systems ${ }^{\mathrm{a}}$ \\
\hline
\end{tabular}

${ }^{a}$ Minneapolis, MN, USA. ${ }^{b}$ Gift from Prof. S C Bell, Department of Obstetrics and Gynaecology, Leicester Warwick Medical School, University of Leicester, UK. 
multinucleate masses at the implantation site was the product of trophoblast-epithelial fusion (Enders 1995). The cells were detected using an interactive planimeter analyzer only in cases where discernability was distinct. The immunopositive cells were identified by detecting positive profiles in digitized images. Following image grabbing and segmentation, digitalized images were subjected to image analysis for estimation of immunopositive area fraction based on manual outlining method and using an optimized gray level threshold yielding normal distribution of image pixels throughout the entire gray scale and shading correction. Pixel calibration was done against the standard provided by the manufacturer. All possible non-overlapping fields in a given section, at least three different sections for each parameter and for each sample, were evaluated. The results of immunopositive area fractions in percentage in different compartments were transformed into rank scores using a standardized 5-scale scoring system: $0(<5 \%), 1(5-25 \%), 2$ (26-50\%), $3(51-75 \%)$, and 4 (76\% and more) as described elsewhere (Kar et al. 2007).

\section{RNA extraction}

The methodological details of RNA extraction have been given elsewhere (Ghosh et al. 2009). Briefly, total RNA was extracted using TRIzol (Invitrogen) and cleaned up with DNase I (Sigma Chemical Co.) and subjected to re-extraction when it was necessary. The yield and purity of the extracted RNA were checked using standard protocols of absorbance ratio between 260 and $280 \mathrm{~nm}$, and 1\% agarose gel electrophoresis (Farrell 1998a). Furthermore, RIN score of individual samples was determined using Agilent 2100 Bioanalyzer, RNA 6000 Nano LabChip kit, and Agilent 2100 Expert Software (Agilent Technologies, Inc., Santa Clara, CA, USA) (Schroeder et al. 2006), and all samples had RIN score $>8.0$.

\section{Quantification of target gene expression by real-time RT-PCR}

The relative expression of candidate genes in reference to $\beta$-actin $(A C T B)$ as the endogenous control in samples collected from all control IgG-and VEGF Mab-treated animals were performed and compared using SYBR Green chemistry-based real-time RT-PCR (Farrell 1998b) on a Bio-Rad platform (iCycler iQTm Real-time PCR detection system, Bio-Rad). Primers for specific genes were designed on Beacon Designer software7 (Labware Scientific, Inc., Milipitas, CA, USA) using NCBI GenBank reference for the rhesus monkey and obtained from Qiagen. Details of primers for target genes are given in Table 5. Two-step RT-PCR for each target RNA (5 $\mu$ g) was done using optimized kits (QuantiTech Reverse Transcription kit for cDNA synthesis and QuantiFast SYBR Green PCR kit) from Qiagen. The calculation of absolute quantification of target transcripts was performed using an optimized method described by Bustin (2002) using standards obtained from Clontech (Takara Bio, Inc., Shiga, Japan) and pooled RNA as internal control, and expressed as log of copy number per $\mu$ g RNA.
Table 5 Primer sequences used in real-time PCR.

\begin{tabular}{lll}
\hline $\begin{array}{l}\text { Gene name } \\
\text { (Gene ID) }\end{array}$ & Primer sequence $\left(5^{\prime}\right.$ to $\left.3^{\prime}\right)$ & \\
\hline ACTB & GTGCGTGACATTAAGGAG (s) & $\boldsymbol{T}_{\mathbf{m}}$ \\
(NM_001033084) & AGGAAGGAAGGTTGGAAG (as) & 49.7 \\
IGF2 & CAGCAATCGGAAGTGAGC (s) & 52.7 \\
(XM_002799440) & TGGAGATGGAACCTGATGG (as) & 52.7 \\
IGFBP1 & AACCAAGGCACAGGAGACATC (s) & 57.5 \\
(XM_001085935) & GTAGACGCACCAGCAGAGC (as) & 57.6 \\
MMP2 & TGGTCCGTGTGAAGTATG (s) & 50.3 \\
(XM_001087335) & AAGTTGTAGGTGGTAGAGC (as) & 50.5 \\
MMP9 & TGACAGAGACAAGAAGTG (s) & 47.5 \\
(XM_001104871) & AGTGATCGGTACATAGG (as) & 46.7 \\
\hline
\end{tabular}

$\mathrm{a}$, antisense; s, sense.

\section{Immunoblots}

Profiles of the candidate proteins in the endometrial homogenates of all samples (control treated, $n=8$; VEGF Mab treated: $n=8$ ) were assessed in samples of $25 \mu$ g protein content along with pre-stained molecular weight markers based on SDSPAGE/western immunoblotting method on nitrocellulose membrane using electrophoresis and transblot equipment, and chemicals obtained from Bio-Rad as described elsewhere (Asubel et al. 1994, Lalitkumar et al. 2005). Final visualization was achieved by using Vectastain ABC immunoperoxidase kits (Vector Laboratories). Respective primary antibody and secondary antibody controls were run simultaneously to examine the specificity of procedure. The molecular weights and semi-quantitative densitometric analysis of bands were determined using a densitometric equipment (Pharos FX Plus Molecular Imager) and an optimized densitometric (PD Quest Advanced) analysis software from Bio-Rad. The integrated measures of optical densities for individual antigens were calculated from log of transmittance for each of the target antigen and normalized with that of $\beta$-actin.

\section{Statistical analysis}

Statistical analyses of data for rank scores were done using non-parametric equivalents of ANOVA test followed by multiple comparison test based on rank sums Wilcoxon's test, and RNA and protein expression data were analyzed using Welch T-test (SPSS17 software; Chicago, IL, USA). The probability level of $P=0.05$ was taken as the limit of significance.

\section{Declaration of interest}

The authors declare that there is no conflict of interest that could be perceived as prejudicing the impartiality of the research reported.

\section{Funding}

This research did not receive any specific grant from any funding agency in the public, commercial, or not-for-profit sector. 


\section{Acknowledgements}

The authors thank the WHO-Rockefeller Foundation Initiative on Implantation Research, the Department of Science and Technology, and the Department of Biotechnology for their funding support for conducting the research studies. The authors gratefully acknowledge the kind gift of mouse MAB against human IGFBP1 from Prof. S C Bell.

\section{References}

Anteby EY, Greenfield C, Natanson-Yaron S, Goldman-Wohl D, Hamani Y, Khudyak V, Ariel I \& Yagel S 2004 Vascular endothelial growth factor, epidermal growth factor and fibroblast growth factor- 4 and -10 stimulate trophoblast plasminogen activator system and metalloproteinase-9. Molecular Human Reproduction 10 229-235. (doi:10.1093/molehr/ gah031)

Asubel FM, Brenet R, Kingston RE, Moore DD, Seidman JG, Smith JA \& Struhl K (Eds) 1994 Immunoblotting and immunodetection. In Current Protocols in Molecular Biology, vol 2, pp 10.8.1-10.8.17. New York: Wiley-Liss.

Bischof P \& Irminger-Finger I 2005 The human cytotrophoblastic cell, a mononuclear chameleon. International Journal of Biochemistry \& Cell Biology 37 1-16. (doi:10.1016/j.biocel.2004.05.014)

Bustin SA 2002 Quantification of mRNA using real time reverse transcription PCR (RT-PCR): trends \& problems. Journal of Molecular Endocrinology 29 23-39. (doi:10.1677/jme.0.0290023)

Cohen M \& Bischof P 2007 Factors regulating trophoblast invasion. Gynecologic and Obstetric Investigation 64 126-130. (doi:10.1159/ 000101734)

Cohen M, Meisser A, Haenggeli L \& Bischof P 2008 Involvement of MAPK pathway in TNF-a-induced MMP-9 expression in human trophoblastic cells. Molecular Human Reproduction 12 225-232. (doi:10.1093/ molehr/gal023)

Coppock HA, White A, Aplin JD \& Westwood M 2004 Matrix metalloprotease-3 and -9 proteolyze insulin-like growth factor-binding protein-1. Biology of Reproduction 71 438-443. (doi:10.1095/biolreprod.103.023101)

Dhara S, Lalitkumar PG, Sengupta J \& Ghosh D 2001 Immunohistochemical localization of insulin-like growth factors I and II at the primary implantation site in the rhesus monkey. Molecular Human Reproduction 7 365-371. (doi:10.1093/molehr/7.4.365)

Egbor M, Ansari T, Morris N, Green CJ \& Sibbons PD 2006 Morphometric placental villous and vascular abnormalities in early- and late-onset preeclampsia with and without fetal growth restriction. British Journal of Obstetrics and Gynecology 113 580-589. (doi:10.1111/j.1471-0528. 2006.00882.x)

Enders AC 1993 The role of different trophoblast types in implantation in primates. In Implantation in Mammals, pp 21-36. Eds LL Gianaroli, AA Campana \& AO Trounson. New York: Raven Press.

Enders AC 1995 Transition from lacunar to villous stage of implantation in the macaque, including establishment of the trophoblastic shell. Acta Anatomica 152 151-169. (doi:10.1159/000147694)

Farrell RE 1998a Electrophoresis of RNA. In RNA Methodologies, 2nd edn, pp 174-177. London: Academic Press.

Farrell RE $1998 b$ Quantitative polymerase chain reaction techniques. In RNA Methodologies, 2nd edn, pp 357-383. London: Academic Press.

Ferretti C, Bruni L, Dangles-Marie V, Pecking AP \& Bellet D 2007 Molecular circuits shared by placental and cancer cells, and their implications in the proliferative, invasive and migratory capacities of trophoblasts. Human Reproduction Update 13 121-141. (doi:10.1093/ humupd/dml048)

Forbes K \& Westwood M 2008 The IGF axis and placental function: a mini review. Hormone Research 69 129-137. (doi:10.1159/000112585)

Ghosh D \& Sengupta J 1993 Anti-nidatory effect of a single, early postovulatory administration of mifepristone (RU 486) in the rhesus monkey. Human Reproduction 8 552-558.
Ghosh D, Dhara S, Kumar A \& Sengupta J 1999 Immunohistochemical localization of receptors for progesterone and oestradiol-17 beta in the implantation site of the rhesus monkey. Human Reproduction $\mathbf{1 4}$ 505-514. (doi:10.1093/humrep/14.2.505)

Ghosh D, Sharkey AM, Charnock-Jones DS, Dhawan L, Dhara S, Smith SK \& Sengupta J 2000 Expression of vascular endothelial growth factor (VEGF) and placental growth factor (PIGF) in conceptus and endometrium during implantation in the rhesus monkey. Molecular Human Reproduction 6 935-941. (doi:10.1093/molehr/6.10.935)

Ghosh D, Bell SC \& Sengupta J 2004 Immunohistological localization of insulin-like growth factor binding protein-1 in primary implantation sites and trauma-induced deciduomal tissues of the rhesus monkey. Placenta 25 197-207. (doi:10.1016/j.placenta.2003.08.011)

Ghosh D, Sharkey AM, Charnock-Jones DS, Smith SK \& Sengupta J 2009 Effect of low-dose mifepristone administration on day 2 after ovulation on transcript profiles in implantation-stage endometrium of rhesus monkeys. Reproduction 138 357-370. (doi:10.1530/REP-08-0442)

Hollborn M, Stathopoulos C, Steffen A, Wiedemann P, Kohen L \& Bringmann A 2007 Positive feedback regulation between MMP-9 and VEGF in human RPE cells. Investigative Ophthalmology \& Visual Science 48 4360-4367. (doi:10.1167/iovs.06-1234)

Irving JA \& Lala PK 1995 Functional role of cell surface integrins on human trophoblast cell migration: regulation by TGF-beta, IGF-II, and IGFBP-1. Experimental Cell Research 217 419-427. (doi:10.1006/excr.1995. 1105)

Irwin JC, Suen L-F, Faessen GH, Popovici RM \& Guidice LC 2001 Insulin like growth factor (IGF)-II inhibition of metalloproteinase-3 and IGF-binding protein-1 suggest partacrine interactions at the deciduas: trophoblast interface during human implantation. Journal of Clinical Endocrinology and Metabolism 86 2060-2064. (doi:10.1210/jc.86.5. 2060)

Jarvenpaa J, Vuoristo JT, Savolainen ER, Ukkola O, Vaskivuo T \& Ryynanen M 2009 Altered expression of angiogenesis-related placental genes in pre-eclampsia associated with intrauterine growth restriction. Gynecological Endocrinology 23 351-355. (doi:10.1080/09513 590701350291)

Jauniaux E, Hempstock J, Greenwold N \& Burton GJ 2003 Trophoblastic oxidative stress in relation to temporal and regional differences in maternal placental blood flow in normal and abnormal early pregnancies. American Journal of Pathology 162 115-125. (doi:10. 1016/S0002-9440(10)63803-5)

Kar M, Ghosh D \& Sengupta J 2007 Histochemical and morphological examination of proliferation and apoptosis in human first trimester villous trophoblast. Human Reproduction 22 2814-2823. (doi:10.1093/ humrep/dem284)

Kim HJ \& Kim TY 2005 Regulation of vascular endothelial growth factor expression by insulin-like growth factor-ll in human keratinocytes, differential involvement of mitogen-activated protein kinases and feedback inhibition of protein kinase C. British Journal of Dermatology 52 418-425. (doi:10.1111/j.1365-2133.2004.06397.x)

Kwon YW, Kwon KS, Moon HE, Park JA, Choi KS, Kim YS, Jang HS, Oh CK, Lee YM, Kwon YG et al. 2004 Insulin-like growth factor-ll regulates the expression of vascular endothelial growth factor by the human keratinocyte cell line HaCaT. Journal of Investigative Dermatology 123 152-158. (doi:10.1111/j.0022-202X.2004.22735.x)

Lalitkumar PGL, Sengupta J \& Ghosh D 2005 Endometrial tumor necrosis factor $\alpha(T N F)$ is a likely mediator of early luteal phase mifepristonemediated negative effector action on the preimplantation embryo. Reproduction 129 323-335. (doi:10.1530/rep.1.00433)

Lash GE, Cartwright JE, Whitley GS, Trew AJ \& Baker PN 1999 The effects of angiogenic growth factors on extravillous trophoblast invasion and motility. Placenta 20 661-667. (doi:10.1053/plac.1999.0427)

Lash GE, Warren AY, Underwood S \& Baker PN 2003 Vascular endothelial growth factor is a chemoattractant for trophoblast cells. Placenta $\mathbf{2 4}$ 549-556. (doi:10.1053/plac.2002.0923)

Nagase H \& Woessner JF 1999 Matrix metalloproteinases. Journal of Biological Chemistry 274 21491-21494. (doi:10.1074/jbc. 274.31.21491)

Nayak NR \& Giudice LC 2003 Comparative biology of the IGF system in endometrium, decidua, and placenta, and clinical implications for foetal growth and implantation disorders. Placenta 24 281-296. (doi:10.1053/ plac.2002.0906) 
Papageorghiou AT, Prefumo F, Leslie K, Gaze DC, Collinson PO \& Thilaganathan B 2008 Defective endovascular trophoblast invasion in the first trimester is associated with increased maternal serum ischemiamodified albumin. Human Reproduction 23 803-806. (doi:10.1093/ humrep/den029)

Prefumo F, Sebire NJ \& Thilaganathan B 2004 Decreased endovascular trophoblast invasion in first trimester pregnancies with high-resistance uterine artery Doppler indices. Human Reproduction 19 206-209. (doi:10.1093/humrep/deh037)

SchiessI B, Innes BA, Bulmer JN, Otun HA, Chadwick TJ, Robson SC \& Lash GE 2009 Localization of angiogenic growth factors and their receptors in the human placental bed throughout normal human pregnancy. Placenta 30 79-87. (doi:10.1016/j.placenta.2008.10.004)

Schroeder A, Mueller O, Stocker S, Salowsky R, Leiber M, Gassmann M, Lightfoot S, Menzel W, Granzow M \& Ragg T 2006 The RIN: an RNA integrity number for assigning integrity values to RNA measurements. BMC Molecular Biology 7 3. (doi:10.1186/1471-2199-7-3)

Sengupta J \& Ghosh D 2002 Blastocyst-endometrium interaction at implantation in the rhesus monkey. Journal of Reproductive Immunology 53 227-239. (doi:10.1016/S0165-0378(01)00091-2)

Sengupta J, Dhawan L \& Ghosh D 2003 Immunohistochemical localization of leukemia inhibitory factor, interleukins 1 and 6 at the primary implantation site in the rhesus monkey. Cytokine 24 277-285. (doi:10. 1016/j.cyto.2003.08.010)

Sengupta J, Lalitkumar PG, Najwa AR, Charnock-Jones DS, Evans AL, Sharkey AM, Smith SK \& Ghosh D 2007 Immunoneutralization of vascular endothelial growth factor inhibits pregnancy establishment in the rhesus monkey (Macaca mulatta). Reproduction 133 1199-1211. (doi:10.1530/rep.1.01228)

Shokry M, Omran OM, Hassan HI, Elsedfy GO \& Hussein MR 2009 Expression of matrix metalloproteinases 2 and 9 in human trophoblasts of normal and preeclamptic placentas: preliminary findings. Experimental and Molecular Pathology 87 219-225. (doi:10.1016/j. yexmp.2009.08.001)

Staun-Ram E \& Shalev E 2005 Human trophoblast function during the implantation process. Reproductive Biology and Endocrinology 356. (doi:10.1186/1477-7827-3-56)

Staun-Ram E, Goldman S, Gabarin D \& Shalev E 2004 Expression and importance of matrix metalloproteinase 2 and 9 (MMP-2 and -9) in human trophoblast invasion. Reproductive Biology and Endocrinology 2 59. (doi:10.1186/1477-7827-2-59)

Tsatsaris V, Goffin F, Munaut C, Brichant JF, Pignon MR, Noel A, Schaaps JP, Cabrol D, Frankenne F \& Foidart JM 2003 Overexpression of the soluble vascular endothelial growth factor receptor in preeclamptic patients: pathophysiological consequences. Journal of Clinical Endocrinology and Metabolism 88 5555-5563. (doi:10.1210/jc.2003-030528)

Uzzo RG, Crispen PL, Golovine K, Makhov P, Horwitz EM \& Kolenko VM 2006 Diverse effects of zinc on NF-kB and AP-1 transcription factors: implications for prostate cancer prognosis. Carcinogenesis 27 1980-1990. (doi:10.1093/carcin/bgl034)

Westwood M, Gibson JM, Davies AJ, Young RJ \& White A 1994 The phosphorylation pattern of insulin-like growth factor-binding protein-1 in normal plasma is different from that in amniotic fluid and changes during pregnancy. Journal of Clinical Endocrinology and Metabolism 79 1735-1741. (doi:10.1210/jc.79.6.1735)

WHO 2003 Semen analysis. In Laboratory Manual for the Examination of Human Semen, 4th edn, part 1, chapter 2, pp 7-113. Cambridge: Cambridge University Press.

Wulff C, Wilson H, Dickson SE, Wiegand SJ \& Fraser HM 2002 Hemochorial placentation in the primate: expression of vascular endothelial growth factor, angiopoietins, and their receptors throughout pregnancy. Biology of Reproduction 66 802-812. (doi:10.1095/biolreprod66.3.802)

Xu P, Wang YL, Piao YS, Bai SX, Xiao ZJ, Jia YL, Luo SY \& Zhuang LZ 2001 Effects of matrix proteins on the expression of matrix metalloproteinase$2,-9$, and -14 and tissue inhibitors of metalloproteinases in human cytotrophoblast cells during the first trimester. Biology of Reproduction 65 240-246. (doi:10.1095/biolreprod65.1.240)

Yu J, Iwasita M, Kudo Y \& Takeda Y 1998 Phosphorylated insulin-like growth factor (IGF)-binding protein-1 (IGFBP-1) inhibits while nonphosphorylated IGFBP-1 stimulates IGF-I-induced amino acid uptake by cultured trophpblast cells. Growth Hormone and IGF Research 8 65-70. (doi:10.1016/S1096-6374(98)80323-7)

Zhou Y, McMaster M, Woo K, Janatpour M, Perry J, Karpanen T, Alitalo K, Damsky C \& Fisher SJ 2002 Vascular endothelial growth factor ligands and receptors that regulate human cytotrophoblast survival are dysregulated in severe preeclampsia and hemolysis, elevated liver enzymes and low platelet syndrome. American Journal of Pathology 160 1405-1423. (doi:10.1016/S0002-9440(10)62567-9)

Received 22 November 2010

First decision 20 December 2010

Accepted 3 February 2011 